\title{
MEMBANGUN DAN MEMELIHARA KOMUNIKASI DALAM KONSELING
}

\author{
Ekawati S. Rukmana \\ Institut Agama Islam Negeri Manado \\ E-mail: ekarukmana@ian-manado.ac.id
}

\begin{abstract}
Communication in daily life is a routine activity carried out by social creatures. Success in building good communication is determined by components effectively, empathy, and good manners between fellow educators, education staff, parents, students, and people. This study aims to find out how to create a communication relationship in counseling between BK teachers and students at Muhammadiyah Senior High School 1 of Yogyakarta. The author uses several methods to collect data, such as interviews and observations. The results of this study explain that the communication process in counseling between BK teachers and students includes several stages, namely: The first start by collecting data about students through a questionnaire tool to several problems and a list of problem notes, the second was the teacher provides opportunities for students to convey the problem they face, the third was empathize with students with verbal and non-verbal language, and the fourth was mentoring continuously to optimize students potential (every student who is naughty or problematic must have a positive side). Establishing and maintaining communication requires the following steps, these are relationship building, problem identification and assessment, facilitating counseling change, and evaluation and termination.
\end{abstract}

Keywords: Communication, Counseling.

\begin{abstract}
ABSTRAK
Komunikasi dalam kehidupan sehari-hari merupakan aktivitas rutin yang dilakukan oleh setiap makhluk sosial. Keberhasilan dalam membangun komunikasi yang baik sangat ditentukan oleh seluruh komponen secara efektif, empati, dan santun, baik antara sesama pendidik, tenaga kependidikan, orang tua, siswa dan masyarakat. Tujuan penelitian ini adalah untuk mengetahui bagaimana konsep membangun hubungan komunikasi dalam konseling antara guru BK dan peserta didik di sekolah SMA Muhammadiyah 1 Yogyakarta. Penulis menggunakan beberapa metode dalam pengumpulan data diantaranya wawancara dan observasi. Hasil penelitian ini menjelaskan bahwa proses komunikasi dalam konseling antara guru BK dan siswa meliputi beberapa tahapan yaitu: 1). Diawali dengan mengumpulkan datadata tentang siswa melalui kuisioner alat ungkap masalah dan daftar catatan masalah, 2). Guru memberikan kesempatan kepada siswa untuk menyampaikan masalah yang dihadapi, 3). Berempati kepada siswa dengan bahasa verbal dan non verbal, 4). Pendampingan secara terus-menerus untuk mengoptimalkan potensi siswa (setiap siswa yang nakal atau bermasalah pasti ada sisi positifnya). Membangun dan memelihara komunikasi diperlukan langkahlangkah sebagai berikut: membangun hubungan, identifikasi dan penilaian masalah, memfasilitasi perubahan konseling, serta evaluasi dan terminasi.
\end{abstract}

Kata Kunci: Komunikasi, Konseling. 


\section{PENDAHULUAN}

Manusia sebagai makhluk sosial selain harus dapat berdiri sendiri juga dapat berhubungan dengan orang lain. Pada waktu mereka berjumpa terbentuklah suatu kelompok dan dalam waktu itu pula terjadilah komunikasi antara seseorang yang satu dengan lainnya, apakah berupa obrolan, bertukar informasi atau pikiran, berdiskusi atau kegiatan lainnya, semuanya dilakukan dalam bentuk bahasa lisan.

Konseling merupakan pemberian bantuan oleh konselor kepada konseli, sehingga pemahaman terhadap kemampuan diri sendiri meningkat dalam menyelesaikan masalah. Adapun tujuan dari konseling yaitu merubah perilaku konseli sesuai dengan kemampuan dan potensi yang dimiliki oleh konselor maupun siswa itu sendiri.

Konseling pada dasarnya mengaitkan komunikasi antara dua pihak, adalah konselor serta klien yang berlangsung dalam suasana konseling. Keberhasilan konseling sangat ditentukan oleh keefektifan komunikasi antara partisipan konseling. Langkah awal dalam proses konseling adalah membangun komunikasi untuk memembina ikatan. Konseling merupakan wujud spesial dari ikatan ataupun komunikasi interpersonal.
Hal ini dimaksudkan bahwa kaidah-kaidah yang berlaku pada proses komunikasi berarti berlaku pula dalam proses konseling, sebab komunikasi merupakan faktor yang sangat penting dalam interaksi manusia.

Membangun serta menjaga atau memelihara komunikasi konseling di lingkungan sekolah tidaklah mudah bagi seorang guru BK atau konselor dengan menangani satu-persatu peserta didik yang begitu banyak dengan permasalahan peserta didik yang berbeda-beda. Apalagi jika guru BK di sekolah-sekolah tidak sesuai dengan bidang keahliannya. Satu atau dua orang guru BK di sekolah tidak akan dapat melayani peserta didik yang begitu banyak. Sesuai dengan aturan Menteri Pendidikan dan Kebudayaan Nomor 111 Tahun 2014 tentang Bimbingan dan Konseling pada Pendidikan Dasar dan Pendidikan Menengah, bahwa setiap satu orang guru BK atau konselor memiliki beban kerja, melayani dan membimbing peserta didik sebanyak 150-160. (Peraturan Menteri Pendidikan dan Kebudayaan Nomor 111 Tahun 2014).

Dalam literatur lain mengatakan bahwa pelaksanaan bimbingan dan konseling sangat dibutuhkan teknik dan keterampilan berkomunikasi yang baik dan 
sopan sehingga dapat membuka hati, pikiran dan perasaan secara suka rela dan ikhlas mengikuti alur pembicaraan yang pada akhirnya klien benar-benar merasa terbimbing oleh konselor itu sendiri. Percakapan antara guru pembimbing (konselor) dengan peserta didik (klien) dalam proses bimbingan dan konseling tidak menggunakan bahasa-bahasa yang kontroversial, tetapi dipilih secara hati-hati sesuai kondisi peserta didik sehingga cenderung menghasilkan persetujuan bersama dalam hal mengatasi atau menyelesaikan suatu persoalan. (Ahmad Zain Sarnoto, 2014).

Penelitian Arina Fithriyana (2014) menemukan bahwa layanan bimbingan kelompok di SMP Nurul Islam Semarang telah terprogram dalam program tahunan bimbingan konseling, tetapi pelaksanaannya sering kali tidak sesuai dengan program yang ada. Kegiatan bimbingan kelompok hanya dilakukan oleh guru BK apabila ada siswa yang membutuhkan layanan ini. Pelaksanaannya pun masih secara konvensional, yaitu hanya dengan berdiskusi tanpa menggunakan teknik-teknik bimbingan kelompok lainnya. Berdasarkan kondisi tersebut, maka disusunlah model bimbingan kelompok dengan teknik permainan simulasi untuk meningkatkan kemampuan komunikasi antar pribadi siswa. Berdasarkan hasil uji efektivitas model dengan menggunakan analisis uji-t, diketahui bahwa model bimbingan kelompok dengan teknik permainan simulasi dapat secara efektif meningkatkan kemampuan komunikasi antar pribadi siswa.

$$
\text { Wulan Furrie }
$$
mengemukakan bahwa komunikasi yang efektif sangat penting bagi proses belajar mengajar, karena sebagai proses dimana keberadaan anak didik dengan beragam budaya, latar belakang keluarga dan perbedaan cara pandang serta kestabilan diri yang masih rentan akan menentukan keberhasilan komunikasi itu sendiri. Keberhasilan komunikasi dalam proses belajar mengajar tidak hanya ditentukan oleh pihak pengajar (guru) tetapi juga kondisi kesiapan mental anak dalam proses komunikasi belajar-mengajar, disamping juga akan didukung oleh pengkondisian lingkungan dan manajemen sekolah itu sendiri.

Sebagai wujud dan kepedulian terhadap proses komunikasi yang terjadi di sekolah antara guru BK dan siswa pelajar SMA se-kota Depok, maka Institut STIAMI mengadakan pelatihan komunikasi efektif bagi bagi guru-guru BK SMA. Hasil dan manfaat dari kegiatan 
pengabdian ini diantaranya adalah meningkatkan kemampuan komunikasi guru-guru BK SMA dalam memahami peserta didik dalam menghadapi proses belajar mengajar sesuai dengan usia dan "kekinian". Peserta cukup antusias dan berpartisipasi aktif dalam kegiatan pelatihan tersebut.

Berdasarkan ulasan di atas, maka tulisan penelitian ini bertujuan untuk mengkaji lebih lanjut terkait peningkatan membangun dan memelihara komunikasi konseling di sekolah.

\section{METODE PENELITIAN}

Penulis memperoleh data tersebut dengan menggunakan beberapa metode pengumpulan data, di antaranya adalah wawancara dan observasi.

Wawancara merupakan proses memperoleh keterangan untuk tujuan penelitian dengan cara tanya jawab secara langsung atau tatap muka antara pewawancara dan responden dengan menggunakan alat yang dinamakan interview guide (panduan wawancara) (Moh. Nazir, 1988). Dalam proses wawancara penulis menggunakan cara interview bebas terpimpin. Penulis membawa pedoman yang hanya merupakan garis besar tentang hal-hal yang akan ditanyakan (Suharsimi
Arikunto, 2019). Subyek wawancara dalam penelitian ini adalah Nur Erlinasari, M.Pd.I sebagai guru BK di SMA Muhammadiyah 1 Yogyakarta.

Observasi merupakan suatu metode pengumpulan data yang digunakan untuk menghimpun data penelitian melalui pengamatan dan penginderaan (Burhan Bungin, 2007). Observasi yang dilakukan merupakan observasi non sistematis dan non participant observation, yaitu pengamatan yang tidak menggunakan instrumen pengamatan, dimana observer tidak terlibat dalam kehidupan orangorang yang diobservasi (observed) (Sutrisno Hadi, 1983)

Waktu dan tempat pelaksanaan pengambilan data dilakukan pada hari Rabu tanggal 2 November 2016 di SMA Muhammadiyah 1 Yogyakarta.

\section{HASIL DAN PEMBAHASAN}

\section{Komunikasi}

Secara etimologis komunikasi berasal dari bahasa Latin communication, dan bersumber juga dari kata communis yang artinya sama, dalam arti kata sama makna. Jadi komunikasi berlangsung apabila antara orang-orang yang terlibat terdapat kesamaan makna mengenai suatu hal yang dikomunikasikan. Sedangkan komunikasi secara terminologis 
komunikasi yang berarti penyampaian suatu pernyataan oleh seseorang kepada orang lain (Onong uchjana effendy, 1993).

Sama halnya seorang guru BK atau konselor menyampaikan sesuatu hal yang berkaitan dengan bimbingan yang diawali dengan komunikasi.

\section{Macam-macam komunikasi}

a. Komunikasi intrapersonal: Penyampaian pesan seseorang kepada dirinya sendiri.

b. Komunikasi interpersonal: Proses pertukaran informasi atau pesan dari seseorang kepada orang lain, yang bersifat dua arah, secara verbal atau non verbal.

c. Komunikasi massa: Penyampaian pesan dari seseorang kepada sekelompok orang atau masyarakat (Onong Uchjana Effendy, 1993).

\section{Membangun komunikasi yang efektif}

a. Perlunya pengumpulan data dan fakta yang dilakukan sebelum kegiatan komunikasi berlangsung. Konselor yang akan berkomunikasi dengan konseli maka konselor harus memiliki data selengkap mungkin yang berkaitan dengan diri konseli, juga harus sudah memiliki fakta-fakta tentang kasus yang dihadapi konseli. Sehingga terjalin hubungan komunikasi yang efektif

b. Perencanaan juga perlu disiapkan berdasarkan data dan fakta yang dimiliki konselor, sehingga konselor memahami apa yang akan dikemukakan atau ditanyakan dan bagaimana menemukannya.

c. Komunikasi, setelah data dan fakta lengkap serta rencana telah disusun maka dapat dilaksanakan proses komunikasi atau proses konseling (Abdullah Masmuh, 2010).

Dapat disimpulkan bahwa membangun komunikasi yang efektif memerlukan data dan fakta yang berkaitan dengan diri seorang konseli, karena sebelum memulai hubungan dengan seorang konseli, seorang konselor harus memiliki persiapan perencanaan yang matang. Sehingga terbentuklah hubungan membangun komunikasi yang efektif serta 
nyaman bagi seorang konseli sekaligus menjadi pendengar yang baik bagi konseli. Komunikasi akan lebih efektif apabila tercapai pesan yang disampaikan dapat diterima dan dipahami oleh konseli.

\section{Teknik-teknik dasar komunikasi dalam konseling}

Teknik konseling memiliki beberapa istilah yaitu keterampilan konseling, strategi konseling, dan teknikteknik konseling. Ketiga istilah tersebut memiliki pengertian yang sama, yaitu strategi yang dipergunakan oleh konselor

dalam membantu klien sehingga berkembang potensi dan mampu mengatasi permasalahan yang nantinya dihadapi klien. Adapun teknik dasar komunikasi konseling antara lain:

a. Attending (perhatian) adalah keterampilan atau teknik yang digunakan konselor untuk memusatkan perhatian kepada klien agar klien merasa dihargai dan terbina suasana yang kondusif sehingga klien bebas mengekspresikan atau mengungkapkan tentang apa saja yang ada dalam pikiran, perasaan maupun tingkah lakunya. b. Opening (pembukaan) adalah keterampilan atau teknik untuk membuka, memulai komunikasi dan hubungan konseling.

c. Acceptance (penerimaan) adalah teknik yang digunakan konselor untuk menunjukan minat dan pemahaman terhadap hal-hal yang dikemukakan klien.

d. Restatement (pengulangan) adalah teknik yang digunakan konselor untuk mengulang, menyatakan kembali pernyataan klien (sebagian atau seluruhnya) yang dianggap penting.

e. Paraphrasing adalah kata-kata konselor untuk menyatakan kembali esensi dari ucapanucapan klien (Namora Lumongga Lubis, 2014).

f. Lead (pengarahan) adalah teknik atau keterampilan yang digunakan konselor untuk mengarahkan pembicaraan klien dari suatu hal ke hal yang lain secara langsung keterampilan ini sering pula disebut keterampilan bertanya. 
g. Silence (diam) adalah suasana hening, tidak ada interaksi verbal antara konselor dan klien dalam proses konseling.

h. Reassurance (penguatan atau dukungan) adalah keterampilan atau teknik yang digunakan oleh konselor untuk memberikan dukungan serta penguatan terhadap pernyataan positif klien agar ia menjadi lebih yakin dan percaya diri.

i. Rejection (penolakan) adalah keterampilan atau teknik yang digunakan konselor untuk melarang klien melakukan rencana yang akan membahayakan serta merugikan dirinya atau orang lain.

j. Advice (saran atau nasehat) adalah keterampilan atau teknik yang digunakan konselor untuk memberikan nasehat atau saran bagi klien agar dia lebih jelas mengenai apa yang akan dikerjakan.

k. Summary (ringkasan atau kesimpulan) adalah keterampilan atau teknik yang digunakan konselor untuk menyimpulkan atau ringkasan mengenai apa yang telah dikemukakan klien pada proses komunikasi konseling (Gantina Komalasari dkk, 2014).

Dari teknik-teknik konseling di atas bisa disimpulkan bahwa komunikasi merupakan metode yang bisaa digunakan untuk membantu konselor dalam memahami perasaanperasaan konseli, baik dari tingkah laku verbal maupun non verbal sebagai usaha untuk menguasai dirinya sendiri serta memahami perubahan yang terjadi pada kehidupannya.

\section{Komunikasi dalam konseling}

Konseling merupakan bantuan yang diberikan kepada individu untuk memecahkan masalah kehidupannya dengan cara wawancara dan dengan cara yang sesuai dengan keadaan yang dihadapi individu untuk mencapai kesejahteraan hidupnya. (Walgito, 2010).

Menurut Dance (dalam Suryanita, 2011) komunikasi dalam konseling adalah suatu proses pemindahan informasi antara dua orang manusia (konselor-konseli) atau lebih yang menimbulkan respon, dengan menggunakan simbol-simbol yang dipahami bersama. 
Berdasarkan pengertian istilah di atas, dapat disimpulkan bahwa komunikasi dalam konseling merupakan suatu proses pemindahan atau penyampaian informasi, pikiran dan sikap antara konselor dan konseli, terjadi dalam konteks tertentu, mempunyai pengaruh tertentu dan ada kesempatan untuk melakukan umpan balik sehingga dapat meningkatkan pemahaman informasi diantara kedua belah pihak.

\section{Membangun dan memelihara}

\section{komunikasi konseling}

Membangun dan memelihara komunikasi konseling sangatlah penting bagi guru BK atau konselor, terlebih lagi ketika berada dilingkungan sekolah, komunikasi yang baik mampu menjadikan suasana dalam memberikan layanan bimbingan serta membangun hubungan berkomunikasi dengan peserta didik menjadi sangat nyaman, sehingga peserta didik tidak lagi menganggap bahwa guru BK adalah polisi sekolah.

Data dalam sebuah penelitian sangatlah penting. Data merupakan langkah yang paling strategis dalam penelitian karena tujuan dari penelitian adalah mendapatkan data dari tempat penelitian (Sugiyono, 2016). Penulis menggunakan teknik wawancara untuk mengumpulkan data dengan hasil sebagai berikut:

1) Konseling

di SMA

Muhammadiyah 1 Yogyakarta

a. Jumlah guru BK ada 7 orang dengan peserta didik 1188. Dari ke 7 guru BK di Sekolah Muhammadiyah 1 Yogyakarta dengan jumlah siswa 1188 sudah memenuhi syarat bahwa setiap satu orang guru BK atau konselor memiliki beban kerja yang sesuai dalam melayani dan membimbing siswa sebanyak 150-160. Ini sesuai dengan peraturan Menteri Pendidikan dan Kebudayaan Nomor 111 Tahun 2014 tentang Bimbingan dan Konseling pada Pendidikan Dasar dan Pendidikan Menengah. (Peraturan Menteri Pendidikan dan Kebudayaan Nomor 111, 2014).

b. Penyusunan program BK di Sekolah diawali dengan mengumpulkan data-data tentang siswa melalui kuisioner dan daftar catatan masalah.

c. Sebagian siswa masih beranggapan guru BK sebagai polisi sekolah dikarenakan guru 
BK mendapat tugas tambahan di bagian kesiswaan berhubungan dengan tata tertib (poin pelanggaran, skorsing, dan ketertiban berpakaian). Siswa menganggap guru BK sebagai polisi sekolah, dikarenakan pelanggaranpelanggaran yang dilakukan siswa itu sendiri ditangani oleh guru BK. Meskipun demikian guru-guru BK di sekolah Muhammadiyah 1 Yogyakarta mendatangkan narasumber dari pihak lain (psikolog).

b. Bentuk layanan BK yaitu layanan individu, konferensi kasus, dan home visit.

c. Layanan konseling dilakukan terhadap siswa dengan permasalahan yang beraneka ragam (tawuran, geng sekolah, dan narkoba).

d. Setiap kasus diselesaikan dengan cara yang berbeda. tergantung berat ringannya permasalahan.

e. Permasalahan siswa diselesaikan oleh guru BK bekerja sama dengan wali kelas, wali murid, guru mata pelajaran, kepolisian, psikolog, tidak merasa keberatan dengan julukan tersebut. Guru BK lebih berfokus menjaga dan membangun hubungan serta melakukan pelayanan komunikasi yang baik dengan siswa-siswanya.

2) Layanan bimbingan dan konseling di SMA Muhammadiyah 1 Yogyakarta.

a. Layanan bimbingan dilakukan berdasarkan program yang telah tersusun dengan dokter maupun pihak lain yang terkait.

f. Setiap siswa yang mempunyai masalah, datang ke Guru BK atas kemauan sendiri maupun dipanggil oleh guru BK.

g. Media yang digunakan selain tatap muka, sosial media (line), penggunaan sosial media tergantung pada permasalahannya, jika masalah yang dihadapi terlalu berat, siswa/wali diharapkan datang ke sekolah untuk bertemu langsung dengan guru BK.

Layanan Bimbingan dan Konseling di Sekolah Muhammadiyah 1 Yogyakarta penulis menyimpulkan bahwa pelayanan di sekolah tersebut sudah memenuhi syarat 
sesuai dengan peraturan Menteri Pendidikan dan Kebudayaan Nomor 111 Tahun 2014 pasal 3, 4, 5 tentang Layanan Bimbingan dan Konseling pada Pendidikan Dasar dan Pendidikan Menengah. (Peraturan Menteri Pendidikan dan Kebudayaan Nomor 111, 2014).

3) Proses konseling di SMA Muhammadiyah 1 Yogyakarta

a. Guru memberikan kesempatan kepada siswa untuk menyampaikan masalah yang dihadapi dengan cara memberikan peserta didik kesempatan untuk menyampaikan masalah, sehingga terbentuklah komunikasi yang baik.

b. Berempati kepada siswa dengan bahasa verbal dan non verbal.

c. Pendampingan dilakukan secara terus-menerus untuk mengoptimalkan potensi siswa (setiap siswa yang bermasalah pasti memiliki sisi positifnya). Konseling yang dilakukan di lingkungan sekolah berfokus pada komunikasi antar pribadi.

\section{PENUTUP}

Komunikasi dalam konseling merupakan suatu proses pemindahan/ penyampain informasi, pikiran dan sikap antara konselor dan konseli, terjadi dalam konteks tertentu, mempunyai pengaruh tertentu dan ada kesempatan untuk melakukan umpan balik sehingga dapat meningkatkan pemahaman informasi di antara kedua belah pihak.

Membangun dan memelihara komunikasi diperlukan langkah-langkah sebagai berikut: membangun hubungan, identifikasi dan penilaian masalah, memfasilitasi perubahan konseling, serta evaluasi dan terminasi.

Dengan berhasilnya membangun dan memelihara komunikasi di lingkungan sekolah pesan yang disampaikan oleh Guru BK bisa diterima dengan baik. Selama proses konseling tidak hentihentinya guru BK memberikan motivasi serta semangat ketika mereka memiliki masalah.

\section{DAFTAR PUSTAKA}

Bungin, Burhan. (2007). Penelitian Kualitatif. Jakarta: Kencana Prenada Media Group.

Cangara, Hafied. (1998). Perencanaan dan Strategi Komunikasi. Jakarta: Rajawali Press. 
Effendi, Onong Uchjana. (1993). Ilmu Komunikasi: Teori dan Praktek. Bandung: PT Remaja Rosdakarya.

Fithriyana, Arina., Sugiharto, Dwi Yuwono Puji., Sugiyo. (2014). Bimbingan Kelompok dengan Teknik Permainan Simulasi Untuk Meningkatkan Kemampuan Komunikasi Antar Pribadi Siswa. Jurnal Bimbingan Konseling. Vol. 3 (2), 137-142.

Furrie, Wulan. (2019). Pelatihan Komunikasi Efektif Bagi GuruGuru SMA Wilayah Kota Depok, "Membangun Komunikasi Efektif dengan Siswa. Jurnal Komunitas: Jurnal Pengabdian Kepada Masyarakat. Vol. 2 (1), 94-99.

Hadi, Sutrisno. (1983). Metodologi Research untuk Penulisan Paper, Skripsi, Thesis dan Disertasi. Yogyakarta: Yayasan Penerbitan Fakultas Psikologi UGM.

Komalasari, Gantina., Wahyuni, Eka., Karsih. 2014. Teori dan Teknik Konseling. Jakarta Barat: PT Indeks.

Nomor 111 Tentang Bimbingan dan Konseling pada Pendidikan Dasar dan Pendidikan Menengah. Kementerian Pendidikan dan Kebudayaan.

Muhammad, Arni. (2005). Komunikasi Organisasi. Jakarta: Bumi Aksara.

Mulyana, Dedy. (2003). Ilmu komunikasi Sebagai Pengantar. Bandung: Rosda Karya.
Lubis, Namora Lumongga. Memahami Dasar-Dasar Konseling dalam Teori dan Praktek. Jakarta: Kencana.

Masmuh, Abdullah. (2010). Komunikasi Organisasi dalam Perspektif Teori dan Praktek. Malang: UMM Press.

Menteri Pendidikan dan Kebudayaan Republik Indonesia. (2014). Peraturan Menteri Pendidikan dan Kebudayaan Republik Indonesia.

Nazir, Moh. (1988). Metode Penelitian. Jakarta: Ghalia Indonesia.

Sarnoto, Ahmad Zain. (2014). Peran Komunikasi dalam Proses Bimbingan dan Konseling. Profesi | Jurnal Ilmu Pendidikan dan Keguruan. Vol. 3 (2), 54-62.

Sugiyono. (2016). Memahami Penelitian Kualitatif. Bandung: CV Alfabeta.

Suharsimi, Arikunto. (2019). Prosedur Penelitian. Jakarta: Rineka Cipta. 